\title{
COLLECTING VERTEBRATE PALAEONTOLOGICAL SPECIMENS IN SASKATCHEWAN
}

TIM TOKARYK, Palaeontological Preparator, Saskatchewan Museum of Natural History, Wascana Park, Regina, Saskatchewan. S4P $3 V 7$

The journal Discover recounts how James Jensen of Brigham Young University found in 1964 "the only Jurassic Period skeleton ever discovered of the turkey-sized dinosaur called Hypsilophodon. He took the bones back to his laboratory still embedded in a block of stone and dirt only to realize that the wrists and forefeet were missing; they were still in the ground." He went back to the site but rock hounds had been there and dug the area up. "It was as if you had put the hill in a paper bag and shaken it up. We may never find another Jurassic Hypsilophodon. We may never know what the forefeet looked like."1

There is a serious debate as to who should have the right to collect. Some geologists and fossil dealers, like Pete Larson will maintain that the scientific community has not lost anything from what commercial fossil dealers have done. ${ }^{1}$ The Society of Vertebrate Palaeontology on the other hand went on record in 1973 as "opposing the sale to the public of fossil specimens of any sort." 3 Everyone agrees however that we should protect the fine fossil specimens of Saskatchewan.

In 1979, the Heritage Property Act was passed. ${ }^{2}$ It is important for everyone to know what the act says concerning the collecting of fossil vertebrates; the major provisions are as follows:

66-(1) Every archaeological or vertebrate palaeontological object found or taken from the land of Saskatchewan after the coming into force of this Act is deemed to be the property of the Crown.

(2) All archaeological or vertebrate palaeontological objects found in or taken from the land of Saskatchewan other than those mentioned in subsection (1) must be registered with the minister within two years from the coming into force of the Act, and where they are not so registered within that two-year period, they become the property of the Crown as soon as the minister gives the person in possession of those objects written notice of the Crown's claim of ownership.

(3) No person shall buy, sell, trade or otherwise dispose of or remove from Saskatchewan for the purpose of selling, trading or otherwise disposing of any archaeological or vertebrate palaeontological object found in or taken from the land of Saskatchewan without written permission of the minister.

(4) In a prosecution under subsection (3), the onus of proving that the object was not found in or taken from land in Saskatchewan is on the person who alleges that it was not so found or taken.

67-(1) No person shall:

(a) carry out a survey;

(b) make surface collecitons; or

(c) conduct excavations;

for the purpose of obtaining archaeological or vertebrate palaeontological objects or information of those objects, unless he holds a valid and subsisting research permit granted pursuant to this section. 
71-(1) Any person, other than a holder of subsisting permit who discovers a previously unknown site containing archaeological or vertebrate palaeontological objects shall, within 15 days of his discovery, notify the minister.

(2) The minister shall provide suitable recognition to any person reporting a discovery mentioned in subsection (1).

73-(1) Any person who contravenes any provision of this Act or the regulations, or any order or direction made or given pursuant to this Act or the regulations, is guilty of an offence and liable on summary conviction [to a fine and/or imprisonment].

The provisions of the Heritage Property Act are purposefully strict in order to preserve the natural history of Saskatchewan.

The Saskatchewan Museum of Natural History, Earth Sciences department, has summer field expeditions to collect vertebrate palaeontological specimens. Some major finds have also come from the public, when individuals discover an important specimen such as the titanothere collected in 1973 (Tillie, 1973) and the mastodon jaw collected in $1981 .{ }^{4}$

The museum welcomes reports of fossil specimens found by private individuals. If the find seems promising, we will make every effort to visit the locality to make an assessment. But we do advise that if you do find any fossil or artifact, leave it there, mark the location and inform Dr. John Storer or myself at the museum. The specimen should not be removed; often a fossil looks solid but when you pick it up, it disintegrates. The museum is also hoping to examine private collections made before the passage of the Act.

If a fossil is a major find, it may be recognized by being reported in scien- tific literature. Even if it isn't a major find, it may be a specimen not well represented in the museum collection, and which we would be most pleased to have donated to us; a warm letter thanking you will follow. But do not dig anything up before you check.

In the early part of this century, western Canada (mainly southern Alberta) was pillaged by collectors from museums all over the world. It wasn't until the National Museum of Canada and the Geological Survey of Canada realized how much fossil material was leaving the country, that they decided to collect for themselves. Although the N.M.C. and the G.S.C. collected a fair amount of material, the other museums who were here first got the "cream of the crop". The only way we can now obtain those fossils that were found in Canada, and are now out of the country, is by purchasing or trading. In future, we hope to prevent such materials from leaving Saskatchewan.

Applications for permits for both archaelogical and vertebrate palaeontological investigations should be made to Saskatchean Culture and Recreation.

'GORMAN, J. 1982. Fossils for Sale. Discover. April, 1982:30-32.

${ }^{2}$ Heritage Property Act, 1979.

${ }^{3}$ Society of Vertebrate Paleontology. 1973. 97:4

${ }^{4}$ TILLIE, R. 1973. A Fossil First for Canada. Blue Jay. 31:242-243. 